\title{
Characteristics and mixing state of amine-containing particles at a rural site in the Pearl River Delta, China
}

\author{
Chunlei Cheng ${ }^{1,2}$, Zuzhao Huang ${ }^{3}$, Chak K. Chan ${ }^{4}$, Yangxi Chu ${ }^{4}$, Mei Li ${ }^{1,2}$, Tao Zhang ${ }^{5}$, Yubo Ou ${ }^{5}$, Duohong Chen ${ }^{5}$, \\ Peng Cheng ${ }^{1,2}$, Lei Li ${ }^{1,2}$, Wei Gao ${ }^{1,2}$, Zhengxu Huang ${ }^{1,2}$, Bo Huang ${ }^{1,2,6}$, Zhong Fu ${ }^{6}$, and Zhen Zhou ${ }^{1,2}$ \\ ${ }^{1}$ Institute of Mass Spectrometer and Atmospheric Environment, Jinan University, Guangzhou 510632, China \\ ${ }^{2}$ Guangdong Provincial Engineering Research Center for on-line source apportionment system of air pollution, \\ Guangzhou 510632, China \\ ${ }^{3}$ Guangzhou Environmental Technology Assessment Center, Guangzhou 510045, China \\ ${ }^{4}$ School of Energy and Environment, City University of Hong Kong, Hong Kong, China \\ ${ }^{5}$ State Environmental Protection Key Laboratory of Regional Air Quality Monitoring, Guangdong Environmental \\ Monitoring Center, Guangzhou 510308, China \\ ${ }^{6}$ Guangzhou Hexin Analytical Instrument Limited Company, Guangzhou 510530, China
}

Correspondence: Mei Li (limei2007@163.com) and Zhen Zhou (zhouzhen@gig.ac.cn)

Received: 19 January 2018 - Discussion started: 30 January 2018

Revised: 17 June 2018 - Accepted: 20 June 2018 - Published: 29 June 2018

\begin{abstract}
Particulate amines play an important role for the particle acidity and hygroscopicity and also contribute to secondary organic aerosol mass. We investigated the sources and mixing states of particulate amines using a single-particle aerosol mass spectrometer (SPAMS) during summer and winter 2014 at a rural site in the Pearl River Delta, China. Amine-containing particles accounted for 11.1 and $9.4 \%$ of the total detected individual particles in summer and winter, respectively. Although the increase in amine-containing particle counts mostly occurred at night, no obvious correlations between amine-containing particles and ambient relative humidity $(\mathrm{RH})$ were found during the sampling period. Among the three markers we considered, the most abundant amine marker was ${ }^{74}\left(\mathrm{C}_{2} \mathrm{H}_{5}\right)_{2} \mathrm{NH}_{2}^{+}$, which was detected in 90 and $86 \%$ of amine-containing particles in summer and winter, followed by amine marker ions of ${ }^{59}\left(\mathrm{CH}_{3}\right)_{3} \mathrm{~N}^{+}$, and ${ }^{86}\left(\mathrm{C}_{2} \mathrm{H}_{5}\right)_{2} \mathrm{NCH}_{2}^{+}$which were detected in less than $10 \%$ of amine-containing particles during sampling period. The amine-containing particles were characterized by high fractions of carbonaceous marker ions, carbon-nitrogen fragments, sulfate, and nitrate in both summer and winter. More than $90 \%$ of amine-containing particles were found to be internally mixed with sulfate throughout the sampling period, while the percentage of amine particles containing nitrate increased from $43 \%$ in summer to $69 \%$ in winter. Robust
\end{abstract}

correlations between the peak intensities of amines, sulfate, and nitrate were observed, suggesting the possible formation of aminium sulfate and nitrate salts. Interestingly, only $8 \%$ of amine particles contained ammonium in summer, while the percentage increased dramatically to $54 \%$ in winter, indicating a relatively ammonium-poor state in summer and an ammonium-rich state in winter. The total ammoniumcontaining particles were investigated and showed a much lower abundance in ambient particles in summer $(3.6 \%)$ than that in winter $(32.6 \%)$, which suggests the ammonium-poor state of amine-containing particles in summer may be related to the lower abundance of ammonia/ammonium in gas and particle phases. In addition, higher abundance of amines in ammonium-containing particles than that of ammonium in amine-containing particles suggests a possible contribution of ammonium-amine exchange reactions to the low abundance of ammonium in amine-containing particles at high ambient RH $(72 \pm 13 \%)$ in summer. The particle acidity of amine-containing particles is estimated via the relative acidity ratio $\left(R_{\mathrm{a}}\right)$, which is defined as the ratio of the sum of the sulfate and nitrate peak areas divided by the ammonium peak area. The $R_{\mathrm{a}}$ was $326 \pm 326$ in summer and $31 \pm 13$ in winter, indicating that the amine-containing particles were more acidic in summer than in winter. However, after including amines along with the ammonium in the acidity calcula- 
tion, the new $R_{\mathrm{a}}^{\prime}$ values showed no seasonal change in summer $(11 \pm 4)$ and winter $(10 \pm 2)$, which suggests that amines could be a buffer for the particle acidity of ammonium-poor particles.

\section{Introduction}

Amines, a group of nitrogen-containing organic compounds, are ubiquitous in the atmospheric gas and particle phases (Ge et al., 2011a). A variety of low molecular weight (LMW) aliphatic amines have been detected in emissions from anthropogenic and natural sources, including animal husbandry, biomass burning, industrial emissions, vehicle exhaust, and marine sources (Rogge et al., 1994; Rappert and Muller, 2005; Calderon et al., 2007; Ngwabie et al., 2007; Facchini et al., 2008; Ge et al., 2011a). LMW aliphatic amines have gas-phase concentrations 2 orders of magnitude lower than that of ammonia $\left(\mathrm{NH}_{3}\right.$; Sorooshian et al., 2008), but are more alkaline than $\mathrm{NH}_{3}$ (Ge et al., 2011b). Due to their strong basicity and water solubility, LMW amines can undergo acid-base reactions with sulfuric and nitric acid to form aminium salts (Angelino et al., 2001; Sorooshian et al., 2007; Pratt et al., 2009), which has been found to enhance new particle formation beyond the amounts produced from reactions between acids and $\mathrm{NH}_{3}$ alone (Kurtén et al., 2008; Berndt et al., 2010; Place et al., 2010; Wang et al., 2010). In addition, once partitioned into the particle phase, these LMW aliphatic amines can enhance aerosol particle hygroscopicity (Chu et al., 2015; Sauerwein et al., 2015). Furthermore, amines can be oxidized by $\mathrm{OH}$ radicals, $\mathrm{NO}_{3}$ radicals, and $\mathrm{O}_{3}$ in the atmosphere to form semi-volatile and non-volatile compounds, some of which are highly toxic (Lee and Wexler, 2013), and which contribute to secondary organic aerosol (SOA) mass (Murphy et al., 2007; Malloy et al., 2009).

The mass concentration and temporal distribution of LMW aliphatic amines in aerosols have been studied extensively in a variety of environments, and LMW aliphatic amines account for $2-12 \%$ of organic mass (Day et al., 2009; Gilardoni et al., 2009; Liu et al., 2009; Russell et al., 2009; Williams et al., 2010). In recent years, real-time singleparticle mass spectrometry has been used to measure the size and chemical composition of individual amine-containing particles with high time resolution. The mixing state and single-particle characteristics of amines have been investigated in laboratory and field environments (Angelino et al., 2001; Moffet et al., 2008; Silva et al., 2008; Pratt et al., 2009; Huang et al., 2012; Qin et al., 2012; Zhang et al., 2012; Gaston et al., 2013; Zauscher et al., 2013). Pratt et al. (2009) studied seasonal differences in aminium and ammonium salts on a single-particle basis using an aerosol time-of-flight mass spectrometer (ATOFMS) coupled with a thermodenuder and reported that the gas-to-particle partitioning of amines is dependent on particle acidity. Healy et al. (2015) investi- gated the temporal distributions of alkylamines at five European sites, and found that alkylamines were internally mixed with both sulfate and nitrate, which suggests that the formation of aminium salts was important at all sites. Zauscher et al. (2013) detected strong signals of an amine marker $\left({ }^{86}\left(\mathrm{C}_{2} \mathrm{H}_{5}\right)_{2} \mathrm{NCH}_{2}^{+}\right)$in biomass burning aerosols associated with the increase in ambient relative humidity, indicating the direct emission of amines from biomass burning and the important influence of high relative humidity $(\mathrm{RH} ;>90 \%)$ on the partitioning process of amines. Huang et al. (2012) determined the mixing state of amine-containing particles in Shanghai and found higher number concentrations of aminecontaining particles in winter than in summer, which they attributed to effective acid-base reactions between sulfuric acid and amines under low-temperature, high-RH conditions. Zhang et al. (2012) measured trimethylamine-containing particles in Guangzhou and found preferential trimethylamine gas-to-particle partitioning during fog events. These field observations emphasize the important role of acid-base reactions in the partitioning of amines from the gas phase to the particle phase. Recent laboratory studies have revealed that the exchange between amine gases and particulate $\mathrm{NH}_{3}$ and/or ammonium also contributes substantially to amine content and results in a depletion of $\mathrm{NH}_{3}$ and/or ammonium in the particle phase (Lloyd et al., 2009; Bzdek et al., 2010; Qiu et al., 2011; Liu et al., 2012; Chan and Chan, 2013; Chu and Chan, 2016, 2017; Sauerwein and Chan, 2017); however, the significance of such exchange reactions in the ambient environment has not been fully explored. Therefore, the influence of ammonia and particle acidity on the distribution of amines in the particle phase should be studied comprehensively through field measurements.

The aim of this study was to investigate the mixing state of a series of LMW aliphatic amines with sulfate, nitrate, and ammonium in individual particles using a single-particle aerosol mass spectrometer (SPAMS) at a rural site in the Pearl River Delta (PRD), China. In order to explore amine origins and gas-to-particle partitioning processes, aminecontaining particles from both summer and winter were classified into three types based on mass spectral patterns. The aminium sulfate and nitrate salt formation processes and internal mixing state with ammonium were used to deduce the relationship between amines and ammonium in the particle phase and the influence of amines on particle acidity.

\section{Methods}

\subsection{Aerosol sampling}

Ambient single particles were collected and analyzed using a SPAMS at the Guangdong atmospheric supersite $\left(22.73^{\circ} \mathrm{N}\right.$, $112.93^{\circ} \mathrm{E}$ ), a rural site in Heshan City in the PRD, China (Fig. S1 in the Supplement). The sampling site is surrounded by villages and experiences little influence from local indus- 
trial emissions (Cheng et al., 2017). The SPAMS was installed at the top of the main building, and aerosols were introduced to the SPAMS through a $2.5 \mathrm{~m}$ copper tube and a silica gel drier. SPAMS sampling was conducted continuously from 18 July to 1 August 2014 and from 27 January to 8 February 2015; several hours of data are missing due to technical maintenance. During the sampling period, hourly $\mathrm{O}_{3}$ concentrations were measured using an $\mathrm{O}_{3}$ analyzer (model 49i, Thermo Scientific). Meteorological data, including temperature, RH, wind speed, and wind direction were also measured during SPAMS sampling.

\subsection{SPAMS}

SPAMS was designed by the Guangzhou Hexin Analytical Instrument Limited Company based on pre-existing ATOFMS principles (Prather et al., 1994; Noble and Prather, 1996). The setup and design of the SPAMS has been detailed previously (Li et al., 2011). Briefly, single particles are sampled through an $80 \mu \mathrm{m}$ critical orifice into the aerodynamic lens at a flow rate of $75 \mathrm{~mL} \mathrm{~min}^{-1}$. Then the particles pass consecutively through two laser beams (diode Nd:YAG, $532 \mathrm{~nm}$ ) spaced $6 \mathrm{~cm}$ apart, and the aerodynamic diameter of the single particle is calculated using the particle flight time and velocity between the two laser beams. The single particle velocity is also used to calculate the precise time at which to fire the desorption and ionization laser ( $\mathrm{Nd}$ :YAG laser, $266 \mathrm{~nm}$ ), which is positioned $12 \mathrm{~cm}$ downstream from the second laser beam. After ionization, the positive and negative ions are detected by a Z-shaped bipolar time-of-flight mass spectrometer. In this work, the ionization laser pulse energy was $0.6 \mathrm{~mJ}$ and the power density was $1.06 \times 10^{8} \mathrm{~W} \mathrm{~cm}^{-2}$ throughout the campaign. The size range of single particles detected by SPAMS ranged from 0.2 to $2 \mu \mathrm{m}$, calibrated with standard polystyrene latex spheres (Nanosphere size standards, Duke Scientific Corp., Palo Alto) of 0.22-2.0 $\mu \mathrm{m}$ diameter before and after the campaign (Cheng et al., 2017).

\subsection{Data analysis}

Particle size and chemical composition were obtained via SPAMS mass spectral analysis using the Computational Continuation Core (COCO; version 3.0) toolkit in Matlab. According to the field studies of ATOFMS and SPAMS, it is difficult to accurately determine the number concentration of ambient particles using SPAMS alone due to the size-dependent transmission efficiencies of particles through the aerodynamic lens and composition dependent matrix effect (Gross et al., 2000; Pratt and Prather, 2012). Thus, the particle counts and size distributions presented in this work should be interpreted as semiquantitative and serve as a basis for comparison analysis (Healy et al., 2012). Based on previous studies using ATOFMS and SPAMS instruments (Angelino et al., 2001; Huang et al., 2012; Qin et al., 2012; Zhang et al.,
2012; Gaston et al., 2013; Zauscher et al., 2013; Healy et al., 2015), amine-containing particles were characterized by marker ions, including $\mathrm{m} / \mathrm{z}:{ }^{59}\left(\mathrm{CH}_{3}\right)_{3} \mathrm{~N}^{+},{ }^{74}\left(\mathrm{C}_{2} \mathrm{H}_{5}\right)_{2} \mathrm{NH}_{2}^{+}$, ${ }^{86}\left(\mathrm{C}_{2} \mathrm{H}_{5}\right)_{2} \mathrm{NCH}_{2}^{+},{ }^{101}\left(\mathrm{C}_{2} \mathrm{H}_{5}\right)_{3} \mathrm{~N}^{+},{ }^{102}\left(\mathrm{C}_{3} \mathrm{H}_{7}\right)_{2} \mathrm{NH}_{2}^{+}$, and ${ }^{143}\left(\mathrm{C}_{3} \mathrm{H}_{7}\right)_{3} \mathrm{~N}^{+}$(Table 1). In this work, a particle was identified as amine-containing if it contained any of the marker ions listed above with a relative peak area (defined as the percentage contribution of the target ion peak area to the sum of all ion peak areas) greater than $1 \%$. It should be noted that amine-containing particles are operationally defined and not exclusive, which also contained various chemical species in addition to amines. According to this criterion, 57452 and 68026 amine-containing particles were identified in summer and winter, respectively, which accounted for 11.1 and $9.4 \%$ of the total detected particles. These number fractions are consistent with previously reported observations in the PRD (Zhang et al., 2012). However, due to the absence of fog events during the campaign, no dramatic increases in amine-containing particles associated with high RH conditions $(\mathrm{RH}>90 \%)$ were observed. Marker ions of ${ }^{59}\left(\mathrm{CH}_{3}\right)_{3} \mathrm{~N}^{+},{ }^{74}\left(\mathrm{C}_{2} \mathrm{H}_{5}\right)_{2} \mathrm{NH}_{2}^{+}$, and ${ }^{86}\left(\mathrm{C}_{2} \mathrm{H}_{5}\right)_{2} \mathrm{NCH}_{2}^{+}$were detected as the most abundant amine species during the sampling period, so particles containing each marker ion were selected to investigate the possible sources and characteristics of amine-containing particles. ${ }^{30} \mathrm{CH}_{3} \mathrm{NH}^{+}$is also an amine marker which has been reported by other single-particle measurement studies (Phares et al., 2003; Glagolenko and Phares, 2004). In this work the peak intensity of ${ }^{30} \mathrm{CH}_{3} \mathrm{NH}^{+}$ was much lower compared with other amine markers, and all the particles containing ${ }^{30} \mathrm{CH}_{3} \mathrm{NH}^{+}$had a strong signal of ${ }^{74}\left(\mathrm{C}_{2} \mathrm{H}_{5}\right)_{2} \mathrm{NH}_{2}^{+}$, so the particles containing ${ }^{30} \mathrm{CH}_{3} \mathrm{NH}^{+}$ were not specifically discussed. An ion peak at $m / z+46$ was detected in the ambient single particles, which could be the amine marker of ${ }^{46}\left(\mathrm{CH}_{3}\right)_{2} \mathrm{NH}_{2}^{+}$and/or ${ }^{46} \mathrm{Na}_{2}^{+}$according to reported studies (Guazzotti et al., 2001; Gaston et al., 2011; Healy et al., 2015). In this work the particles containing $m / z+46$ had no other amine markers as listed above; besides, these particles were enriched with sodium salts like ${ }^{62} \mathrm{Na}_{2} \mathrm{O}^{+},{ }^{81} \mathrm{Na}_{2} \mathrm{Cl}^{+}$, and ${ }^{147} \mathrm{Na}\left(\mathrm{NO}_{3}\right)_{2}^{-}$. Thus, $m / z+46-$ containing particles were not classified as amine-containing particles and are likely sea salts.

\section{Results and discussion}

\subsection{Seasonal variation in amine-containing particles}

Spatial distributions of amine-containing particles associated with backward trajectories $(48 \mathrm{~h}$ ) of air masses at $500 \mathrm{~m}$ levels above the ground during the sampling period are shown in Fig. 1. Cluster trajectories were calculated by MeteoInfo (Wang, 2014), and the box plots were conducted by the Histbox program based on Igor Pro (Wu et al., 2018; $\mathrm{Wu}$ and $\mathrm{Yu}, 2018)$. In summer, high amine-containing particle counts were associated with air masses of Cluster 3 

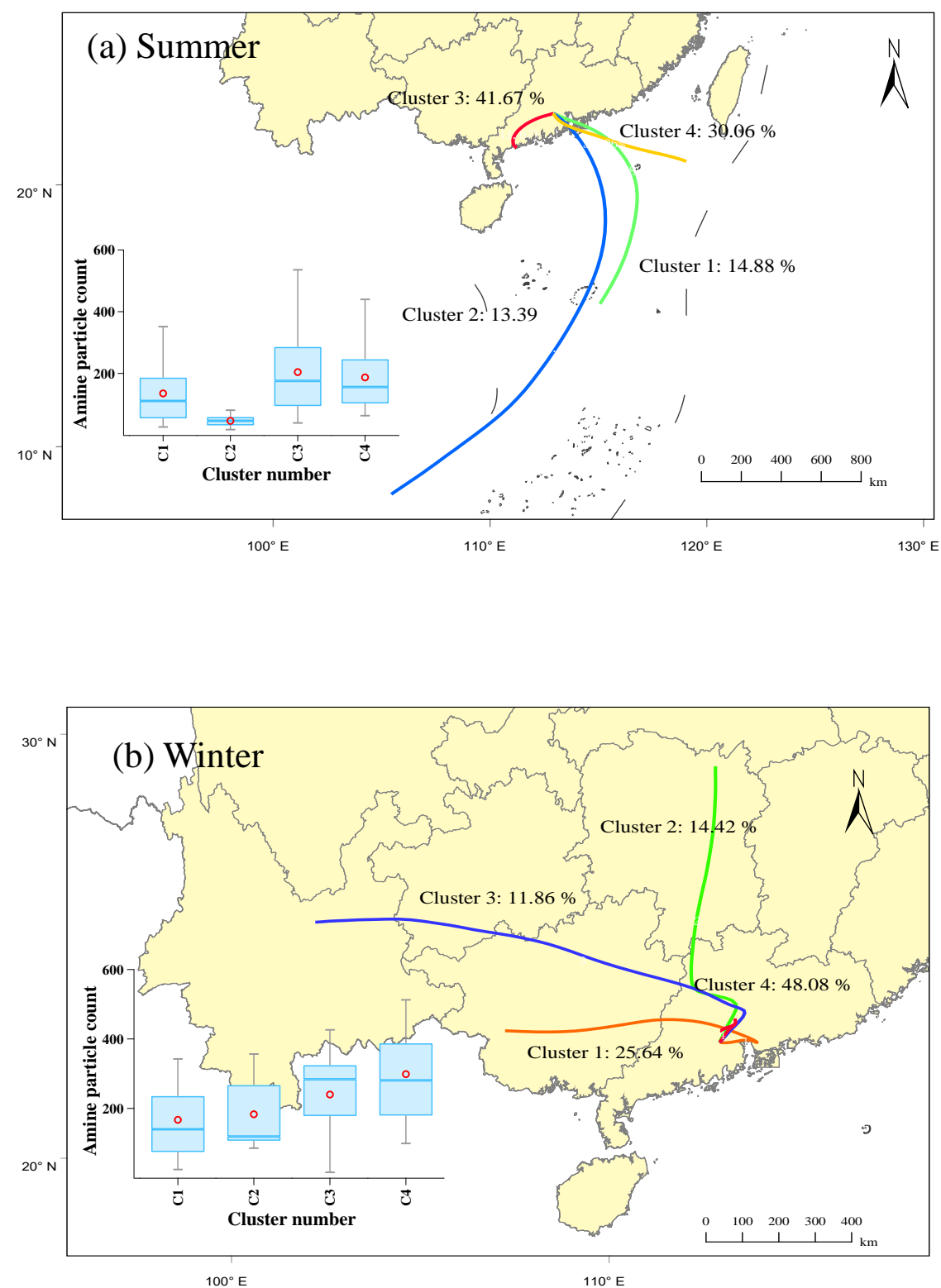

Figure 1. Spatial distributions of amine-containing particle counts associated with backward trajectories $(48 \mathrm{~h})$ of air masses at $500 \mathrm{~m} \mathrm{levels}$ above the ground during the sampling period: (a) summer (from 18 July to 1 August 2014), (b) winter (from 27 January to 8 February 2015 ).

$(41.67 \%)$ and Cluster $4(30.06 \%)$ (Fig. 1a) from the continent and South China Sea separately, suggesting that the majority of amine-containing particles came from anthropogenic sources and coastal emissions. However, in winter, large amounts of amine-containing particles were associated with air masses of Cluster 4 (48.08\%; Fig. 1b), indicating that amine-containing particles were related primarily with local emissions, such as animal husbandry, biomass burning, and vehicle exhaust. Anthropogenic emissions from Foshan and Guangzhou may also have contributed, as the sampling site is only 40 and $56 \mathrm{~km}$ from these cities, respectively
(Fig. S1). Besides, the stagnant meteorological conditions associated with Cluster 4 also facilitated the partitioning of amines from the gas to particle phase in winter.

The amine-containing particle count observed in summer (57 452) was lower than observed in winter (68 026), but the abundance of amine-containing particles relative to the total particle count was higher in summer $(11.1 \%)$ than in winter $(9.4 \%)$. Temporal variations in total amine-containing particles and three amine marker ions are shown in Fig. 2. The increase in amine-containing particles was mostly associated with high RH at night in summer, while no direct connec- 


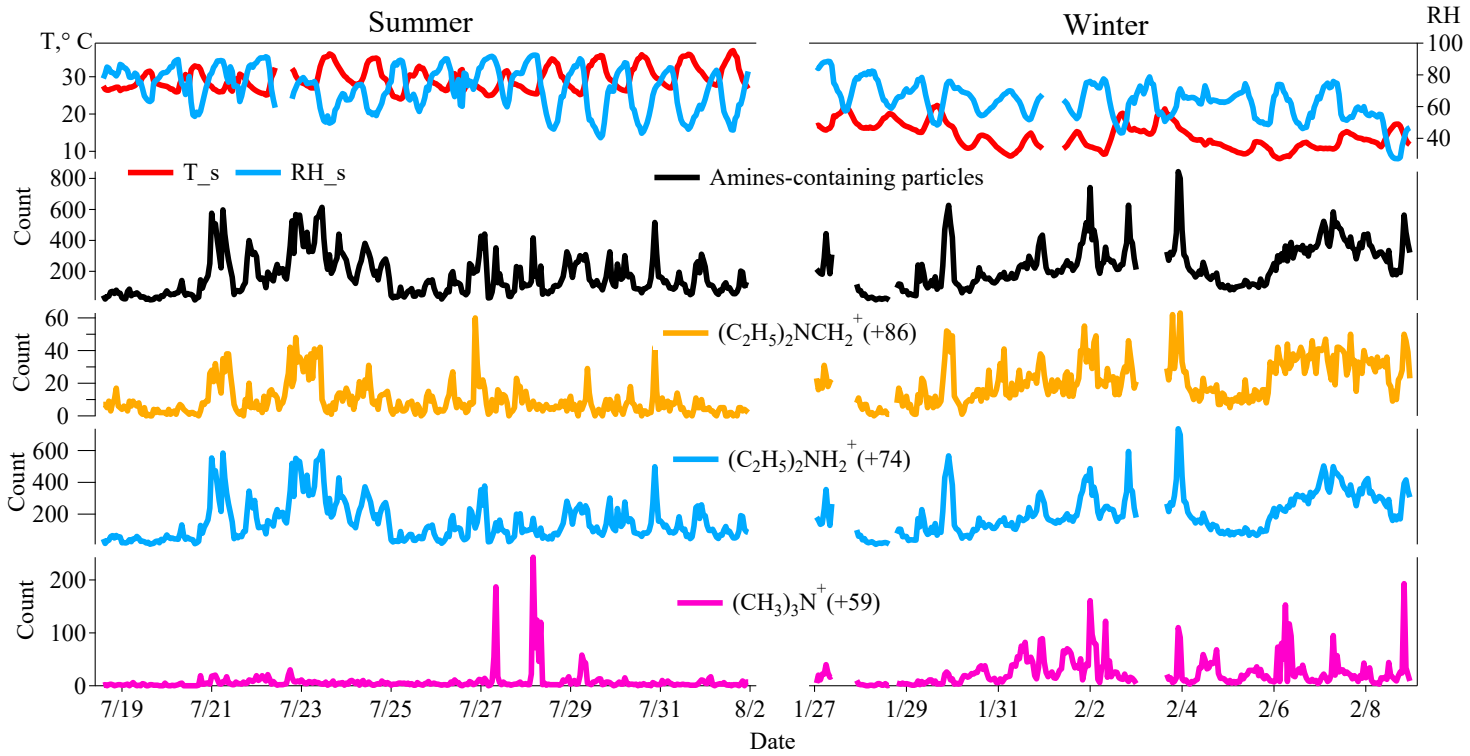

Figure 2. Temporal variations in relative humidity $(\mathrm{RH})$, temperature $(T)$, total amine-containing particles, and three major marker ionscontaining amine particles $\left({ }^{59}\left(\mathrm{CH}_{3}\right)_{3} \mathrm{~N}^{+},{ }^{74}\left(\mathrm{C}_{2} \mathrm{H}_{5}\right)_{2} \mathrm{NH}_{2}^{+},{ }^{86}\left(\mathrm{C}_{2} \mathrm{H}_{5}\right)_{2} \mathrm{NCH}_{2}^{+}\right)$in Heshan, China during the sampling periods.

Table 1. Marker ions chosen for the amine-containing particles.

\begin{tabular}{ll}
\hline Marker ion & Alkylamine assignment \\
\hline${ }^{59}\left(\mathrm{CH}_{3}\right)_{3} \mathrm{~N}^{+}$ & Trimethylamine (TMA) $^{\mathrm{a}}$ \\
${ }^{74}\left(\mathrm{C}_{2} \mathrm{H}_{5}\right)_{2} \mathrm{NH}_{2}^{+}$ & Diethylamine (DEA) $^{\mathrm{b}}$ \\
${ }^{86}\left(\mathrm{C}_{2} \mathrm{H}_{5}\right)_{2} \mathrm{NCH}_{2}^{+}$ & DEA, TEA, DPA \\
${ }^{101}\left(\mathrm{C}_{2} \mathrm{H}_{5}\right)_{3} \mathrm{~N}^{+}$ & Triethylamine (TEA) $^{\mathrm{d}}$ \\
${ }^{102}\left(\mathrm{C}_{3} \mathrm{H}_{7}\right)_{2} \mathrm{NH}_{2}^{+}$ & Dipropylamine (DPA) \\
${ }^{143}\left(\mathrm{C}_{3} \mathrm{H}_{7}\right)_{3} \mathrm{~N}^{+}$ & Tripropylamine (TPA) ${ }^{\mathrm{f}}$ \\
\hline
\end{tabular}

References are as follows: ${ }^{\mathrm{a}}$ Zhang et al. (2012), Gaston et al. (2013); ${ }^{\mathrm{b}}$ Angelino et al. (2001); ${ }^{\mathrm{c}}$ Huang et al. (2012), Zauscher et al. (2013), Qin et al. (2012); ${ }^{\text {G }}$ aston et al. (2013);

${ }^{\mathrm{e}}$ Pratt et al. (2009); ${ }^{\mathrm{f}}$ Healy et al. (2015).

tion between particle counts and RH was found in winter (Fig. S2a and b). High counts of amine-containing particles that extended to a few days were found from 22 to 24 July (in summer) and from 5 to 8 February (in winter). Among the three markers we considered, the most abundant amine marker was ${ }^{74}\left(\mathrm{C}_{2} \mathrm{H}_{5}\right)_{2} \mathrm{NH}_{2}^{+}$, which was detected in 90 and $86 \%$ of amine-containing particles in summer and winter (Table 2), followed by ${ }^{59}\left(\mathrm{CH}_{3}\right)_{3} \mathrm{~N}^{+}$and ${ }^{86}\left(\mathrm{C}_{2} \mathrm{H}_{5}\right)_{2} \mathrm{NCH}_{2}^{+}$ which were detected in less than $10 \%$ of amine-containing particles during the sampling period. The amine particles containing ${ }^{74}\left(\mathrm{C}_{2} \mathrm{H}_{5}\right)_{2} \mathrm{NH}_{2}^{+}$and ${ }^{86}\left(\mathrm{C}_{2} \mathrm{H}_{5}\right)_{2} \mathrm{NCH}_{2}^{+}$both exhibited a similar pattern with total particles containing amine suggesting a similar emission source of ${ }^{74}\left(\mathrm{C}_{2} \mathrm{H}_{5}\right)_{2} \mathrm{NH}_{2}^{+}$ and ${ }^{86}\left(\mathrm{C}_{2} \mathrm{H}_{5}\right)_{2} \mathrm{NCH}_{2}^{+}$(Fig. 2). The temporal trend of particles containing ${ }^{59}\left(\mathrm{CH}_{3}\right)_{3} \mathrm{~N}^{+}$were different from those of ${ }^{74}\left(\mathrm{C}_{2} \mathrm{H}_{5}\right)_{2} \mathrm{NH}_{2}^{+}$and ${ }^{86}\left(\mathrm{C}_{2} \mathrm{H}_{5}\right)_{2} \mathrm{NCH}_{2}^{+}$; and the two sudden episodes of ${ }^{59}\left(\mathrm{CH}_{3}\right)_{3} \mathrm{~N}^{+}$occurred from 27 to 29 July in summer were possibly due to the emission sources of trimethylamine (TMA).

The diurnal patterns of amine-containing particles are investigated in summer and winter (Fig. 3) and both showed higher counts at night. The small increase from 06:00 to 09:00 LT (local time) throughout the campaign may have been due to local emissions from vehicle exhaust (Cadle and Mulawa, 1980). Several field studies have revealed the strong correlation between RH and particulate amines, suggesting that high RH in fog events is favorable for the gasto-particle partitioning of amines (Jeong et al., 2011; Rehbein et al., 2011; Huang et al., 2012; Zhang et al., 2012). In this work, although the increase in amine-containing particle counts mostly occurred at night, no obvious correlations between diurnal amine-containing particles and $\mathrm{RH}$ were found in summer $\left(r^{2}=0.33\right)$ and winter $\left(r^{2}=0.0003\right)$ (Fig. S2). Although lower temperature facilitates the partitioning of gaseous amines into the particulate phase (Huang et al., 2012), no significant temperature differences were found both in summer (day: $32 \pm 1.1^{\circ} \mathrm{C}$; night: $27.5 \pm 1.1^{\circ} \mathrm{C}$ ) and winter (day: $15 \pm 1.4^{\circ} \mathrm{C}$; night: $13 \pm 0.8^{\circ} \mathrm{C}$ ), which suggests a minor influence of temperature on the diurnal pattern of amine-containing particles. The increase in aminecontaining particles at night may be influenced by particle acidity and emission sources of amines (Murphy et al., 2007; Kurtén et al., 2008; Silva et al., 2008). 
Table 2. Seasonal distributions of amine-containing particles and three major amine markers in summer and winter in the PRD, China.

\begin{tabular}{lrrrrr}
\hline & \multicolumn{2}{c}{$\begin{array}{c}\text { Summer } \\
\text { (18 July-1 August 2014) }\end{array}$} & & \multicolumn{2}{c}{$\begin{array}{c}\text { Winter } \\
\text { (27 January-8 February 2015) }\end{array}$} \\
\cline { 2 - 3 } Particle type & Count & Percentage $(\%)^{*}$ & & Count & Percentage $(\%)^{*}$ \\
\hline Total amines & 57452 & & & 68026 & \\
$59\left(\mathrm{CH}_{3}\right)_{3} \mathrm{~N}^{+}$ & 2581 & 4.5 & 6894 & 10 \\
$74\left(\mathrm{C}_{2} \mathrm{H}_{5}\right)_{2} \mathrm{NH}_{2}^{+}$ & 51442 & 90 & & 58272 & 86 \\
${ }^{86}\left(\mathrm{C}_{2} \mathrm{H}_{5}\right)_{2} \mathrm{NCH}_{2}^{+}$ & 3185 & 5.5 & & 6119 & 9 \\
\hline
\end{tabular}

* The percentage of each amine marker ion in total detected amine-containing particles.

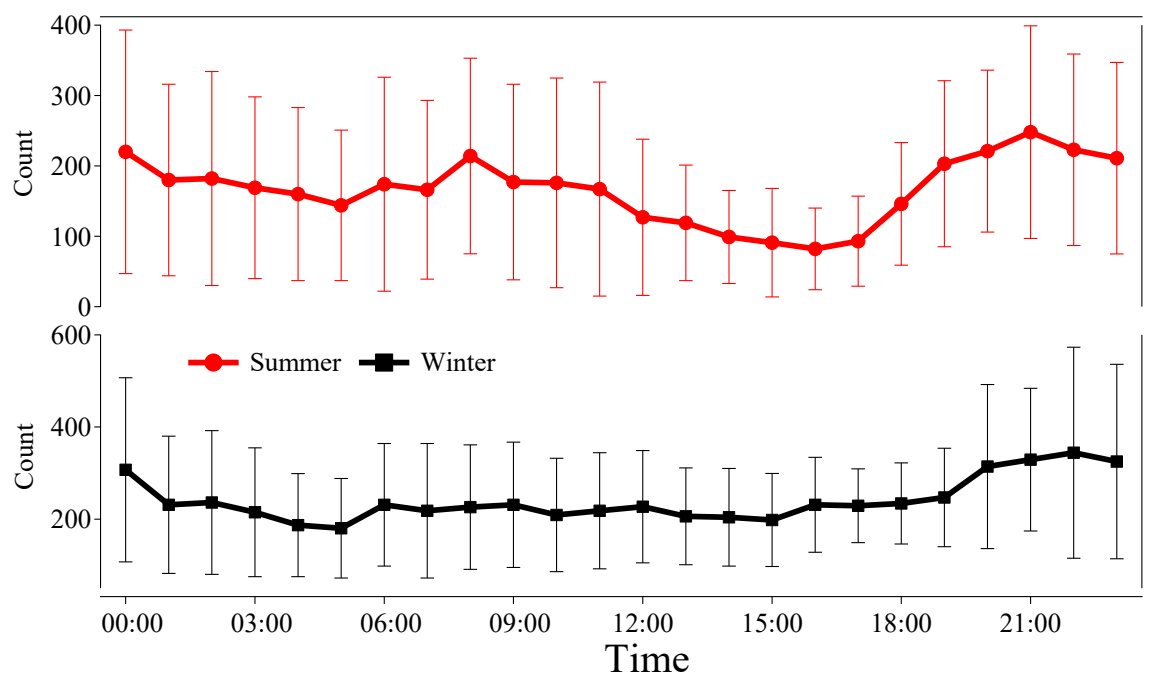

Figure 3. Diurnal variations in amine-containing particle counts in summer and winter in Heshan.

\subsection{Characteristics of amine-containing particles}

The average mass spectra of amine-containing particles in summer and winter are shown in Fig. 4. The aminecontaining particles were characterized by high fractions of carbonaceous marker ions, including ${ }^{27} \mathrm{C}_{2} \mathrm{H}_{3}^{+},{ }^{29} \mathrm{C}_{2} \mathrm{H}_{5}^{+}$, ${ }^{36} \mathrm{C}_{3}^{+},{ }^{37} \mathrm{C}_{3} \mathrm{H}^{+},{ }^{43} \mathrm{C}_{2} \mathrm{H}_{3} \mathrm{O}^{+},{ }^{48} \mathrm{C}_{4}^{+},{ }^{51} \mathrm{C}_{4} \mathrm{H}_{3}^{+},{ }^{53} \mathrm{C}_{4} \mathrm{H}_{5}^{+}$, ${ }^{60} \mathrm{C}_{5}^{+},{ }^{63} \mathrm{C}_{5} \mathrm{H}_{3}^{+},{ }^{65} \mathrm{C}_{5} \mathrm{H}_{5}^{+}$, and ${ }^{77} \mathrm{C}_{6} \mathrm{H}_{5}^{+}$; and amine marker ions of ${ }^{30} \mathrm{CH}_{3} \mathrm{NH}^{+},{ }^{59}\left(\mathrm{CH}_{3}\right)_{3} \mathrm{~N}^{+},{ }^{74}\left(\mathrm{C}_{2} \mathrm{H}_{5}\right)_{2} \mathrm{NH}_{2}^{+}$, and ${ }^{86}\left(\mathrm{C}_{2} \mathrm{H}_{5}\right)_{2} \mathrm{NCH}_{2}^{+}$in the positive mass spectrum in both summer and winter. The negative mass spectrum was characterized by strong carbon-nitrogen fragments like ${ }^{26} \mathrm{CN}^{-}$and ${ }^{42} \mathrm{CNO}^{-}$, as well as abundant secondary ions of ${ }^{46} \mathrm{NO}_{2}^{-}$, ${ }^{62} \mathrm{NO}_{3}^{-},{ }^{80} \mathrm{SO}_{3}^{-}$, and ${ }^{97} \mathrm{HSO}_{4}^{-}$in both summer and winter. In many field studies, aged carbonaceous particles always contain abundant secondary ions of sulfate, nitrate, and ammonium. Interestingly, in this work, the signals of ${ }^{18} \mathrm{NH}_{4}^{+}$ were weak and only observed in less than $10 \%$ of aminecontaining particles in summer, but a moderate signal of ${ }^{18} \mathrm{NH}_{4}^{+}$was detected in half of the amine-containing particles in winter. The low ${ }^{18} \mathrm{NH}_{4}^{+}$signal in amine-containing parti- cles may have been due to the emission sources of ammonia and particle acidity, which will be discussed in Sect. 3.3.

The unscaled size-resolved number distributions of total amine-containing particles and amine particles containing three marker ions of ${ }^{59}\left(\mathrm{CH}_{3}\right)_{3} \mathrm{~N}^{+},{ }^{74}\left(\mathrm{C}_{2} \mathrm{H}_{5}\right)_{2} \mathrm{NH}_{2}^{+}$, and ${ }^{86}\left(\mathrm{C}_{2} \mathrm{H}_{5}\right)_{2} \mathrm{NCH}_{2}^{+}$are shown in Fig. 5. The amine-containing particles exhibited unimodal distributions in the submicron mode from 0.4 to $1.5 \mu \mathrm{m}$ in both summer and winter, which may have resulted from gaseous amine condensation on and/or reaction with fine mode particles from anthropogenic emissions. Although amine-containing particles peaked at the size range of $0.5-0.7 \mu \mathrm{m}$ in both summer and winter, a broader size range of amine-containing particles was observed in winter, which may be due to more complex anthropogenic emission sources of primary particles in winter. The particles containing ${ }^{74}\left(\mathrm{C}_{2} \mathrm{H}_{5}\right)_{2} \mathrm{NH}_{2}^{+}$showed similar variation patterns as total amine-containing particles both in summer and winter. However, particles containing ${ }^{59}\left(\mathrm{CH}_{3}\right)_{3} \mathrm{~N}^{+}$ and ${ }^{86}\left(\mathrm{C}_{2} \mathrm{H}_{5}\right)_{2} \mathrm{NCH}_{2}^{+}$showed less distinct peaks in winter. 

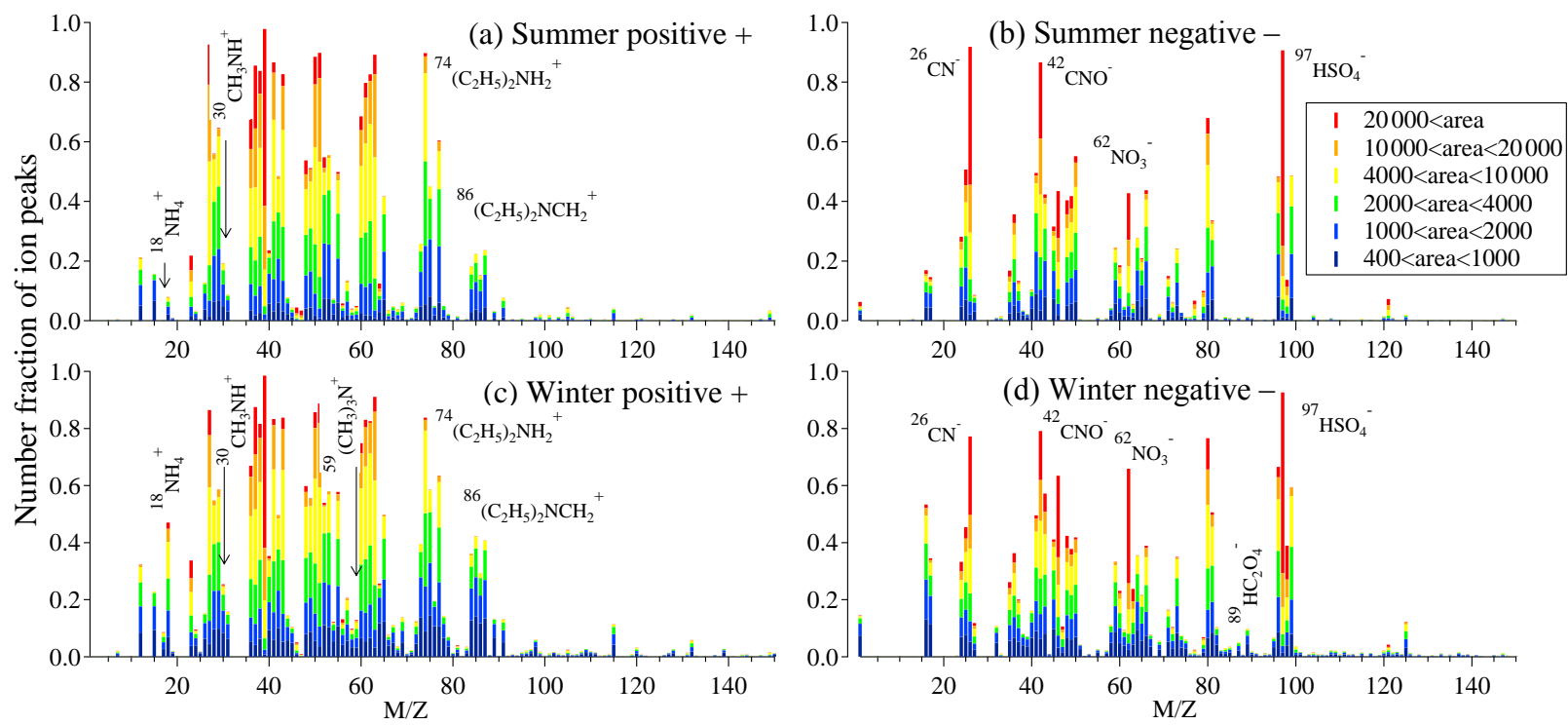

Figure 4. Average ion mass spectra of amine-containing particles in summer and winter. The color bars represent each peak area corresponding to a specific ion in individual particles.

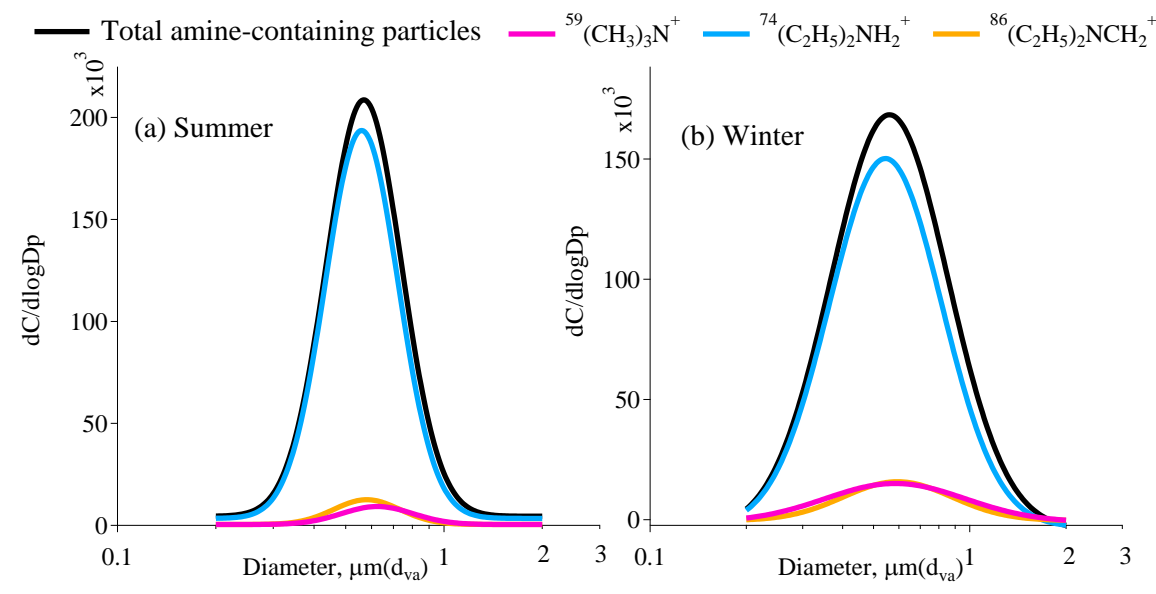

Figure 5. Unscaled size-resolved number distributions of total amine-containing particles and amine particles containing the three marker ions of ${ }^{59}\left(\mathrm{CH}_{3}\right)_{3} \mathrm{~N}^{+},{ }^{74}\left(\mathrm{C}_{2} \mathrm{H}_{5}\right)_{2} \mathrm{NH}_{2}^{+}$, and ${ }^{86}\left(\mathrm{C}_{2} \mathrm{H}_{5}\right)_{2} \mathrm{NCH}_{2}^{+}$in summer and winter in Heshan.

\subsection{Mixing state of amine-containing particles}

To investigate the mixing state of amine-containing particles, the abundances of sulfate-, nitrate-, and ammoniumcontaining amine particles are shown in Table 3. More than $90 \%$ of amine-containing particles were found to be internally mixed with sulfate throughout the sampling period. The abundance of nitrate in amine particles increased from $43 \%$ in summer to $69 \%$ in winter. The internal mixing state of amines with sulfate and nitrate had also been found in Qin et al. (2012), which reported that the amine-rich particles consisted of $18 \pm 10 \%$ amines by mass in the form of aminium sulfate and nitrate salts in summer in Riverside, California.
In this work, the high abundances of sulfate and nitrate in amine-containing particles suggest the possible formation of aminium sulfate and nitrate salts. Interestingly, only $8 \%$ of amine-containing particles mixed with ammonium $\left(\mathrm{NH}_{4}^{+}\right)$in summer, while the percentage increased dramatically to $54 \%$ in winter, indicating a relatively poor $\mathrm{NH}_{4}^{+}$state in summer and a rich $\mathrm{NH}_{4}^{+}$state in winter.

The seasonal differences in the mixing state of amines and $\mathrm{NH}_{4}^{+}$may be influenced by the seasonal variation in the source strength of $\mathrm{NH}_{4}^{+}$. To investigate the temporal variation and abundance of $\mathrm{NH}_{4}^{+}$in total detected single particles, the total particles containing $\mathrm{NH}_{4}^{+}$were identified with a relative area of ${ }^{18} \mathrm{NH}_{4}^{+}$larger than $1 \%$. Using this crite- 
Table 3. The abundances of ammonium-, nitrate- and sulfatecontaining particles in total amine-containing particles.

\begin{tabular}{lrr}
\hline Marker ions & Summer & Winter \\
\hline${ }^{18} \mathrm{NH}_{4}^{+}$ & $8 \%$ & $54 \%$ \\
${ }^{62} \mathrm{NO}_{3}^{-}$ & $43 \%$ & $69 \%$ \\
${ }^{97} \mathrm{HSO}_{4}^{-}$ & $91 \%$ & $94 \%$ \\
\hline
\end{tabular}

The marker ions of ${ }^{18} \mathrm{NH}_{4}^{+},{ }^{62} \mathrm{NO}_{3}^{-}$, and

${ }^{97} \mathrm{HSO}_{4}^{-}$were chosen to represent ammonium, nitrate, and sulfate.

rion, 18336 and 235312 particles containing $\mathrm{NH}_{4}^{+}$were detected in summer and winter separately, accounting for 3.6 and $32.6 \%$ of the total detected particles, respectively. The averaged positive and negative ion mass spectra of particles containing $\mathrm{NH}_{4}^{+}$are exhibited in Fig. 6. During the entire sampling period the particles containing $\mathrm{NH}_{4}^{+}$were characterized by abundant hydrocarbon fragments and secondary organic species like ${ }^{43} \mathrm{C}_{2} \mathrm{H}_{3} \mathrm{O}^{+}$and ${ }^{89} \mathrm{HC}_{2} \mathrm{O}_{4}^{-}$, as well as strong signals of ${ }^{26} \mathrm{CN}^{-},{ }^{42} \mathrm{CNO}^{-},{ }^{62} \mathrm{NO}_{3}^{-}$, and ${ }^{97} \mathrm{HSO}_{4}^{-}$, indicating an mixing state of particles containing $\mathrm{NH}_{4}^{+}$. Also, $20 \%$ of particles containing $\mathrm{NH}_{4}^{+}$contained ${ }^{74}\left(\mathrm{C}_{2} \mathrm{H}_{5}\right)_{2} \mathrm{NH}_{2}^{+}$, which indicates a close connection between $\mathrm{NH}_{3}$ and diethylamine (DEA), possibly due to the similar emission sources.

Temporal variations in total amine-containing particles, total ammonium-containing particles (containing $\mathrm{NH}_{4}^{+}$) and particles containing both ammonium and amine $\left(\mathrm{NH}_{4}^{+}\right.$amine) are shown in Fig. 7. The total particles containing $\mathrm{NH}_{4}^{+}$and $\mathrm{NH}_{4}^{+}$-amine particles were both much lower in summer than in winter, and the particles containing $\mathrm{NH}_{4}^{+}$ and amine-containing particles showed a robust linear correlation in winter $\left(r^{2}=0.63\right.$; Fig. S3). This seasonal difference may be due to the low emission sources of ammonia and preferred partitioning in the gas phase in summer. Backward trajectories analysis (Fig. 1) showed that in summer the air mass was mainly from south of the sampling site and linked to the marine region with low emissions of anthropogenic pollutants. By contrast, in winter, the air mass was mainly from the northwest of the sampling site and associated with relatively polluted megacities like Guangzhou and Foshan. In this work, the lower abundance of $\mathrm{NH}_{4}^{+}$was observed in summer $(\mathrm{RH}=72 \pm 13 \%)$ than in winter $(\mathrm{RH}=63 \pm 11 \%)$, suggesting a more important influence of sources than $\mathrm{RH}$ on the seasonal trends of particles containing $\mathrm{NH}_{4}^{+}$.

The temporal variations in the peak areas of amines, ammonium, sulfate, and nitrate in amine-containing particles are shown in Fig. 8. The peak areas of amines and sulfate had similar variation patterns both in summer and winter, and the linear regression between them showed robust correlations both in summer $\left(r^{2}=0.69\right)$ and winter $\left(r^{2}=0.72\right)$ (Fig. S4), indicating the formation of aminium sulfate salt during the entire sampling period. However, the peak areas of amines and nitrate only exhibited similar trends in winter, and the linear regression between them showed a better correlation in winter $\left(r^{2}=0.78\right)$ than in summer $\left(r^{2}=0.52\right)$ (Fig. S4), suggesting the possible formation of aminium nitrate salt in winter. A low peak area of ammonium was found in the amine-containing particles in summer which was in accordance with the small amount of $\mathrm{NH}_{4}^{+}$-amine particles. However, in winter, the peak area of ammonium was comparable with amines and they both exhibited similar temporal trends. In this work the particle acidity of amine-containing particles is represented by the relative acidity ratio $\left(R_{\mathrm{a}}\right)$, which is developed by Denkenberger et al. (2007) and Pratt et al. (2009), defined as the ratio of the sum of the sulfate and nitrate peak areas divided by the ammonium peak area (Denkenberger et al., 2007; Pratt et al., 2009; Cheng et al., 2017). Huang et al. (2013) obtained a robust correlation $\left(r^{2}=0.82\right)$ between the particle acidity calculated from inorganic ions obtained from an online analyzer for monitoring aerosols and gases (MARGA) and relative acidity ratio obtained from single particle mass spectrometer, allowing us to use $R_{\mathrm{a}}$ for comparison of particle acidity (Huang et al., 2013). The $R_{\mathrm{a}}$ was $326 \pm 326$ in summer and $31 \pm 13$ in winter (Fig. 8), indicating that the amine-containing particles were more acidic in summer than in winter.

Although high acidity promotes gaseous ammonia partitioning, extremely low ammonium peak areas were found for the amine-containing particles in summer (Fig. 8), which may be associated with ammonium-amine exchange reactions in addition to the low emission source of ammonia. The exchange between amine gases and particulate $\mathrm{NH}_{3}$ and/or ammonium highly depends on the RH and particle acidity (Chan and Chan, 2013; Chu and Chan, 2016). According to the study of Sauerwein and Chan, the co-uptake of dimethylamine (DMA) and ammonia $\left(\mathrm{NH}_{3}\right)$ by sulfuric acid particles at $50 \% \mathrm{RH}$ led to particle-phase dimethylaminium $\left(\mathrm{DMAH}^{+}\right)$to ammonium $\left(\mathrm{NH}_{4}^{+}\right)$with a molar ratio up to 4 times that of gas-phase DMA to ammonia molar ratio (0.1 and 0.5$)$, suggesting the displacement of $\mathrm{NH}_{4}^{+}$by DMA during the uptake process (Sauerwein and Chan, 2017). In this work, the ambient RH and acidic particles containing abundant sulfate and nitrate were similar to the experimental conditions used in Sauerwein and Chan (2017). In summer, $8 \%$ of amine-containing particles contained $\mathrm{NH}_{4}^{+}$, while $25 \%$ of ammonium-containing particles contained amines (Fig. 7). Although the gas-phase concentrations of amines and $\mathrm{NH}_{3}$ are not quantified, higher abundance of amines in ammonium-containing particles than that of ammonium in amine-containing particles suggests possible ammoniumamine exchange reactions in acidic particles in summer.

As strong bases, the presence of amines could have an impact on the particle acidity. After including amines along with the ammonium in the relative acidity ratio calculation, the new $R_{\mathrm{a}}^{\prime}$ values (redefined as the ratio of the sum of the sulfate and nitrate peak areas to the sum of the ammonium and amine peak areas) decrease to $11 \pm 4$ and $10 \pm 2$ in summer and winter, respectively, which are 30 and 3 times lower 

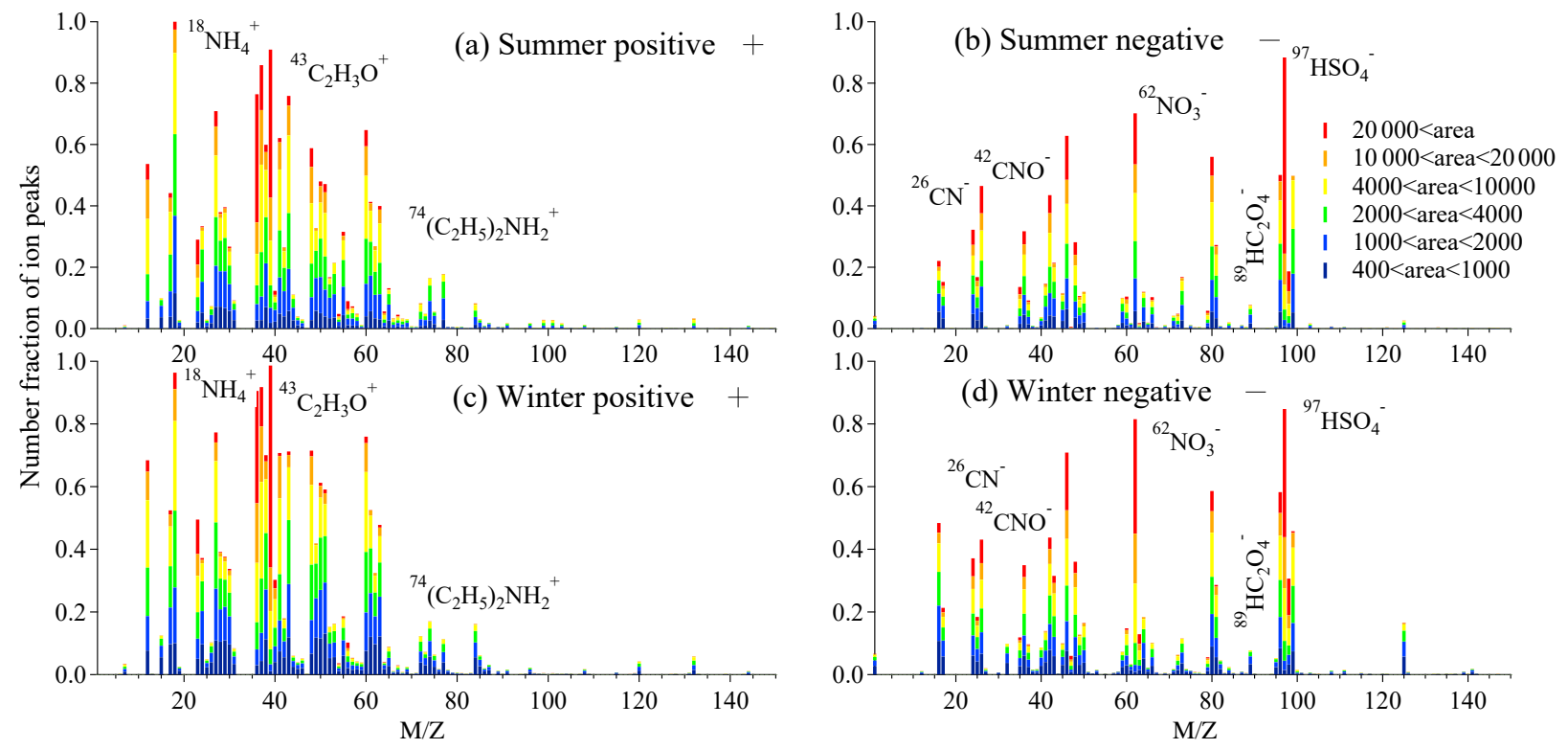

Figure 6. Mass spectra of total ammonium-containing (containing $\mathrm{NH}_{4}^{+}$) particles in summer and winter. The color bars represent each peak area corresponding to a specific fraction in individual particles.

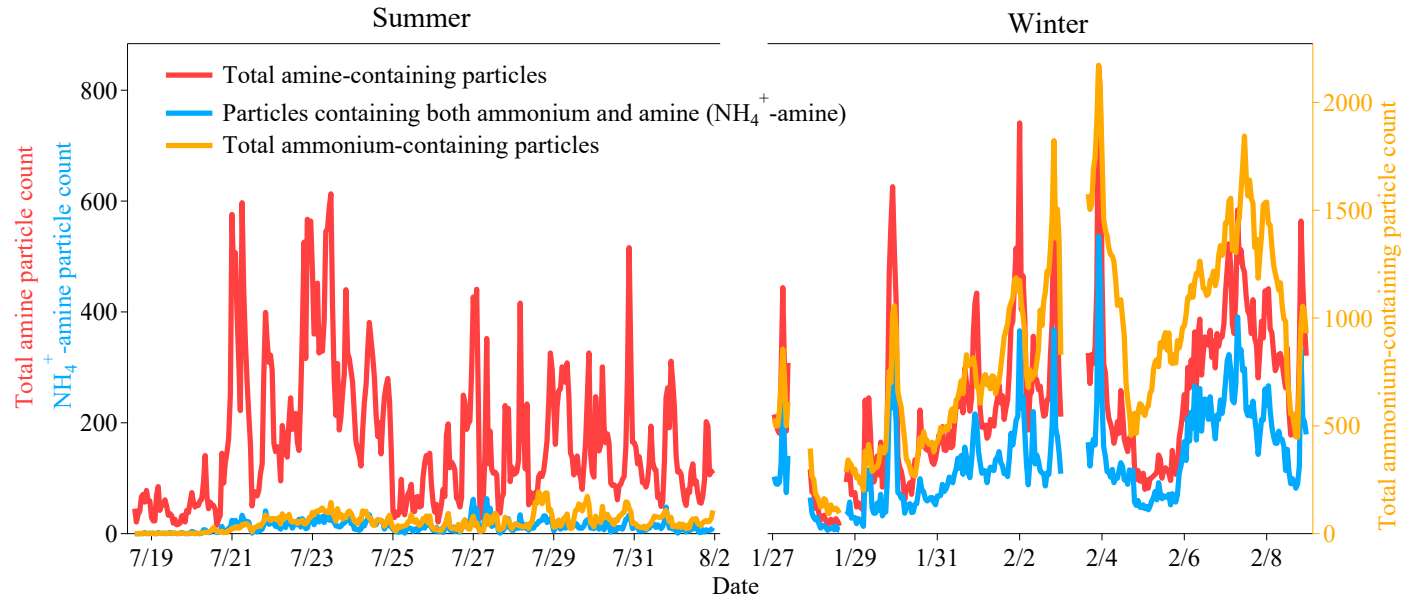

Figure 7. Temporal variations in total amine-containing particles, total ammonium-containing particles, and particles containing both ammonium and amine $\left(\mathrm{NH}_{4}^{+}\right.$-amine) during sampling period in Heshan.

than $R_{\mathrm{a}}$ values, respectively. The $R_{\mathrm{a}}^{\prime}$ showed no obvious seasonal change of particle acidity, which suggests that amines could be a buffer for the particle acidity of ammonium-poor particles, implying that it is reasonable to consider amines to calculate particle acidity and actual $\mathrm{pH}$.

\section{Summary and conclusions}

Amine-containing particles were investigated using a single particle aerosol mass spectrometer from 18 July to $1 \mathrm{Au}$ gust 2014, and from 27 January to 8 February 2015 in
Heshan, China. Amine-containing particles accounted for 11.1 and $9.4 \%$ of the total detected single particles in summer and winter, respectively; both seasons were dominated by the amine marker ${ }^{74}\left(\mathrm{C}_{2} \mathrm{H}_{5}\right)_{2} \mathrm{NH}_{2}^{+}$in 90 and $86 \%$ of amine-containing particles in summer and winter, respectively. Amine markers ${ }^{59}\left(\mathrm{CH}_{3}\right)_{3} \mathrm{~N}^{+}$and ${ }^{86}\left(\mathrm{C}_{2} \mathrm{H}_{5}\right)_{2} \mathrm{NCH}_{2}^{+}$ were detected in 4.5 and $5.5 \%$ of amine-containing particles in summer, while their percentages both increased 2 times in winter. The amine particles contained ${ }^{74}\left(\mathrm{C}_{2} \mathrm{H}_{5}\right)_{2} \mathrm{NH}_{2}^{+}$and ${ }^{86}\left(\mathrm{C}_{2} \mathrm{H}_{5}\right)_{2} \mathrm{NCH}_{2}^{+}$both exhibited a similar variation pattern with total amine-containing particles suggesting a similar 


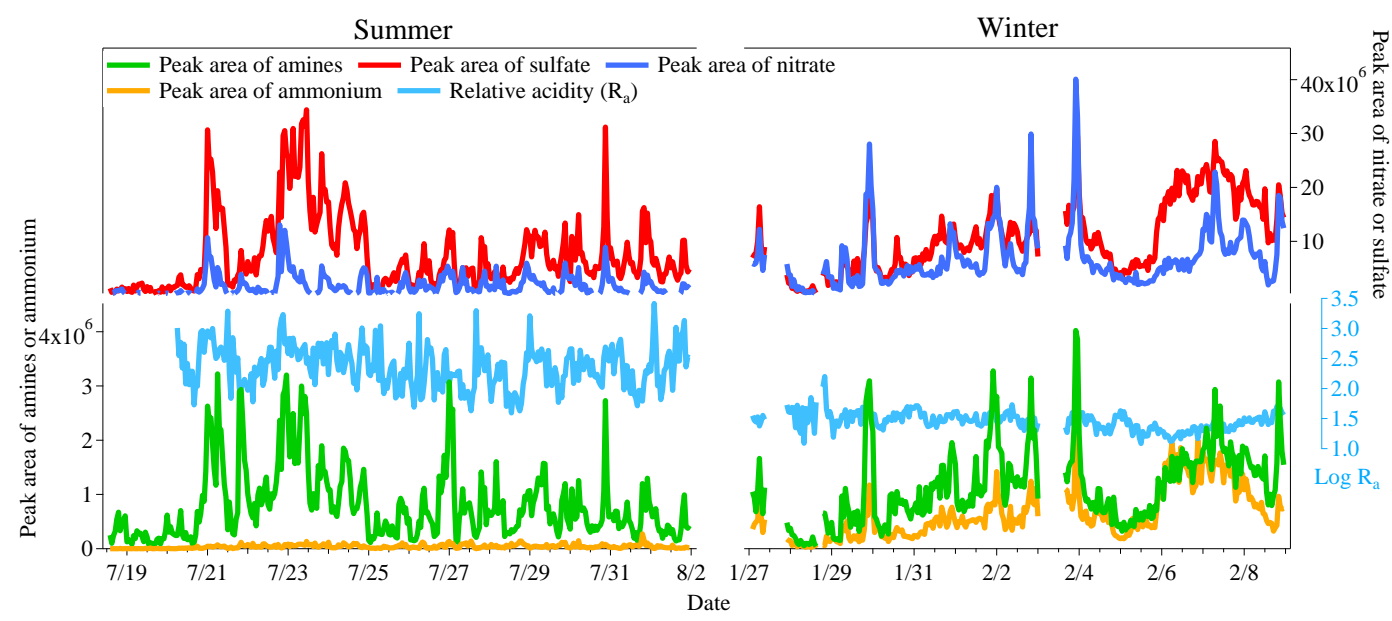

Figure 8. Temporal variations in the peak areas of amines, ammonium, sulfate, and nitrate in amine-containing particles during summer and winter. The relative acidity ratio $\left(R_{\mathrm{a}}\right)$, which was calculated as the ratio of the total sulfate and nitrate peak areas to the ammonium peak area, is plotted as $\log \left(R_{\mathrm{a}}\right)$.

emission source of ${ }^{74}\left(\mathrm{C}_{2} \mathrm{H}_{5}\right)_{2} \mathrm{NH}_{2}^{+}$and ${ }^{86}\left(\mathrm{C}_{2} \mathrm{H}_{5}\right)_{2} \mathrm{NCH}_{2}^{+}$, while the particles containing ${ }^{59}\left(\mathrm{CH}_{3}\right)_{3} \mathrm{~N}^{+}$showed different temporal trends, and two sudden increase episodes of ${ }^{59}\left(\mathrm{CH}_{3}\right)_{3} \mathrm{~N}^{+}$in summer were possibly due to the emission sources of trimethylamine. Although the increase in amine-containing particle counts mostly occurred at night, no obvious correlations between amine-containing particles and RH were found in summer $\left(r^{2}=0.33\right)$ or winter $\left(r^{2}=\right.$ $0.0003)$. More than $90 \%$ of amine-containing particles contained strong signals of sulfate throughout the sampling period, while 43 and $69 \%$ of amine particles contained nitrate in summer and winter, respectively. Only $8 \%$ of amine particles contained ammonium in summer, while the percentage increased dramatically to $54 \%$ in winter. Due to the lower percentage of total ammonium-containing particles in summer $(3.6 \%)$ than it in winter $(32.6 \%)$, the relatively ammonium-poor state of amine-containing particles in summer may be due to the lower abundance of ammonia/ammonium in the gas and particle phases. Besides, $8 \%$ of amine-containing particles contained ammonium while $25 \%$ of ammonium-containing particles contained amines in summer, suggesting a possible contribution of ammonium-amine exchange reactions to the low abundance of ammonium in amine-containing particles at high ambient RH (72 $\pm 13 \%)$ in summer. In addition, the presence of aminium salts affects the water activities and osmotic coefficients of aqueous solutions, which may influence the calculation of $\mathrm{pH}$ using aerosol thermodynamic models (Sauerwein et al., 2015). Furthermore, it should be noted that the measured $\mathrm{pH}$ of bulk ambient aerosols may not be representative of the actual single-particle acidity. As pointed out in Pratt et al. (2009) and in this work, the mixing state of aerosols should be considered in order to comprehensively estimate the aerosol $\mathrm{pH}$. Several recent studies have reported a "missing" source of sulfate produced from the oxidation of $\mathrm{SO}_{2}$ by $\mathrm{NO}_{2}$ during haze episodes with high ambient RH in northern China, and the neutralization of particulate ammonium is a key factor in this formation mechanism (Cheng et al., 2016; Wang et al., 2016). Our study reveals that amines have a potential influence on particle acidity, which could also impact this sulfate formation process during haze episodes. In order to discuss the potential role of amines in this sulfate formation pathway, real-time concentrations of amines, ammonium, sulfate, nitrate, and their precursors must be available. The results of this study suggest that amine chemistry involving particle acidity and mixing state with sulfate, nitrate, and ammonium may have an important role in the aging process of particles in regions with high concentration of amines.

Data availability. The observational data including SPAMS and meteorological parameters used in this study are available from corresponding authors upon request (limei2007@163.com).

Supplement. The supplement related to this article is available online at: https://doi.org/10.5194/acp-18-9147-2018-supplement.

Author contributions. CC and ML designed the experiments. TZ, YO and DC carried them out. CC prepared the manuscript with contributions from all co-authors.

Competing interests. Bo Huang and Zhong Fu are both employees at Guangzhou Hexin Analytical Instrument Limited Company. 
Special issue statement. This article is part of the special issue "Multiphase chemistry of secondary aerosol formation under severe haze". It does not associated with a conference.

Acknowledgements. This work was financially supported by the NSFC of Guangdong Province (grant nos. 2017A030310180, 2015A030313339), National Natural Science Foundation of China (grant no. 21607056), National Key Technology R\&D Program (grant no. 2014BAC21B01), Guangdong Province Public Interest Research and Capacity Building Special Fund (grant no. 2014B020216005), the Guangdong Applied Science and Technology Research and Development (grant no. 2015B020236003), Fundamental Research Funds for the Central Universities (grant no. 21617455), National research program for key issues in air pollution control (grant no. DQGG0107), National Key Research and Development Program of China (grant no. 2016YFC0208503), and Pearl River Nova Program of Guangzhou (no. 201506010013).

Chak K. Chan would like to acknowledge funding support from the General Fund of National Natural Science Foundation of China (grant no. 41675117). The authors acknowledge sampling support from the Guangdong atmospheric supersite. Helpful comments and revisions from Anthony S. Wexler, Hang Su, and Misha I. S. Boehm are acknowledged as well.

Edited by: Daniel Knopf

Reviewed by: three anonymous referees

\section{References}

Angelino, S., Suess, D. T., and Prather, K. A.: Formation of aerosol particles from reactions of secondary and tertiary alkylamines: Characterization by aerosol time-of-flight mass spectrometry, Environ. Sci. Technol., 35, 3130-3138, https://doi.org/10.1021/es0015444, 2001.

Berndt, T., Stratmann, F., Sipilä, M., Vanhanen, J., Petäjä, T., Mikkilä, J., Grüner, A., Spindler, G., Lee Mauldin III, R., Curtius, J., Kulmala, M., and Heintzenberg, J.: Laboratory study on new particle formation from the reaction $\mathrm{OH}+\mathrm{SO}_{2}$ : influence of experimental conditions, $\mathrm{H}_{2} \mathrm{O}$ vapour, $\mathrm{NH}_{3}$ and the amine tert-butylamine on the overall process, Atmos. Chem. Phys., 10, 7101-7116, https://doi.org/10.5194/acp-10-7101-2010, 2010.

Bzdek, B. R., Ridge, D. P., and Johnston, M. V.: Amine exchange into ammonium bisulfate and ammonium nitrate nuclei, Atmos. Chem. Phys., 10, 3495-3503, https://doi.org/10.5194/acp10-3495-2010, 2010.

Cadle, S. H. and Mulawa, P. A.: Low-molecular-weight aliphatic amines in exhaust from catalyst-equipped cars, Environ. Sci. Technol., 14, 718-723, 1980.

Calderon, S. M., Poor, N. D., and Campbell, S. W.: Estimation of the particle and gas scavenging contributions to wet deposition of organic nitrogen, Atmos. Environ., 41, 4281-4290, https://doi.org/10.1016/j.atmosenv.2006.06.067, 2007.

Chan, L. P. and Chan, C. K.: Role of the Aerosol Phase State in Ammonia/Amines Exchange Reactions, Environ. Sci. Technol., 47, 5755-5762, https://doi.org/10.1021/es4004685, 2013.

Cheng, Y., Zheng, G., Wei, C., Mu, Q., Zheng, B., Wang, Z., Gao, M., Zhang, Q., He, K., Carmichael, G., Pöschl, U., and Su,
H.: Reactive nitrogen chemistry in aerosol water as a source of sulfate during haze events in China, Science Advances, 2, e1601530, https://doi.org/10.1126/sciadv.1601530, 2016.

Cheng, C., Li, M., Chan, C. K., Tong, H., Chen, C., Chen, D., Wu, D., Li, L., Wu, C., Cheng, P., Gao, W., Huang, Z., Li, X., Zhang, Z., Fu, Z., Bi, Y., and Zhou, Z.: Mixing state of oxalic acid containing particles in the rural area of Pearl River Delta, China: implications for the formation mechanism of oxalic acid, Atmos. Chem. Phys., 17, 9519-9533, https://doi.org/10.5194/acp17-9519-2017, 2017.

Chu, Y. and Chan, C. K.: Reactive Uptake of Dimethylamine by Ammonium Sulfate and Ammonium SulfateSucrose Mixed Particles, J. Phys. Chem. A, 121, 206-215, https://doi.org/10.1021/acs.jpca.6b10692, 2016.

Chu, Y. and Chan, C. K.: Role of oleic acid coating in the heterogeneous uptake of dimethylamine by ammonium sulfate particles, Aerosol Sci. Tech., 51, 988-997, https://doi.org/10.1080/02786826.2017.1323072, 2017.

Chu, Y. X., Sauerwein, M., and Chan, C. K.: Hygroscopic and phase transition properties of alkyl aminium sulfates at low relative humidities, Phys. Chem. Chem. Phys., 17, 19789-19796, https://doi.org/10.1039/c5cp02404h, 2015.

Day, D. A., Takahama, S., Gilardoni, S., and Russell, L. M.: Organic composition of single and submicron particles in different regions of western North America and the eastern Pacific during INTEX-B 2006, Atmos. Chem. Phys., 9, 5433-5446, https://doi.org/10.5194/acp-9-5433-2009, 2009.

Denkenberger, K. A., Moffet, R. C., Holecek, J. C., Rebotier, T. P., and Prather, K. A.: Real-time, single-particle measurements of oligomers in aged ambient aerosol particles, Environ. Sci. Technol., 41, 5439-5446, https://doi.org/10.1021/es0703291, 2007.

Facchini, M. C., Decesari, S., Rinaldi, M., Carbone, C., Finessi, E., Mircea, M., Fuzzi, S., Moretti, F., Tagliavini, E., Ceburnis, D., and O'Dowd, C. D.: Important Source of Marine Secondary Organic Aerosol from Biogenic Amines, Environ. Sci. Technol., 42, 9116-9121, https://doi.org/10.1021/es8018385, 2008.

Gaston, C. J., Furutani, H., Guazzotti, S. A., Coffee, K. R., Bates, T. S., Quinn, P. K., Aluwihare, L. I., Mitchell, B. G., and Prather, K. A.: Unique ocean derived particles serve as a proxy for changes in ocean chemistry, J. Geophys. Res.-Atmos., 116, D18310, https://doi.org/10.1029/2010JD015289, 2011.

Gaston, C. J., Quinn, P. K., Bates, T. S., Gilman, J. B., Bon, D. M., Kuster, W. C., and Prather, K. A.: The impact of shipping, agricultural, and urban emissions on single particle chemistry observed aboard the R/V Atlantis during CalNex, J. Geophys. Res.Atmos., 118, 5003-5017, https://doi.org/10.1002/jgrd.50427, 2013.

Ge, X. L., Wexler, A. S., and Clegg, S. L.: Atmospheric amines - Part I. A review, Atmos. Environ., 45, 524-546, https://doi.org/10.1016/j.atmosenv.2010.10.012, $2011 \mathrm{a}$.

Ge, X. L., Wexler, A. S., and Clegg, S. L.: Atmospheric amines - Part II. Thermodynamic properties and gas/particle partitioning, Atmos. Environ., 45, 561-577, https://doi.org/10.1016/j.atmosenv.2010.10.013, 2011 b.

Gilardoni, S., Liu, S., Takahama, S., Russell, L. M., Allan, J. D., Steinbrecher, R., Jimenez, J. L., De Carlo, P. F., Dunlea, E. J., and Baumgardner, D.: Characterization of organic ambient aerosol during MIRAGE 2006 on three platforms, Atmos. Chem. Phys., 9, 5417-5432, https://doi.org/10.5194/acp-9-5417-2009, 2009. 
Glagolenko, S. and Phares, D. J.: Single-particle analysis of ultrafine aerosol in College Station, Texas, J. Geophys. Res.-Atmos., 109, D18205, https://doi.org/10.1029/2004jd004621, 2004.

Gross, D. S., Galli, M. E., Silva, P. J., and Prather, K. A.: Relative sensitivity factors for alkali metal and ammonium cations in single particle aerosol time-of-flight mass spectra, Anal. Chem., 72, 416-422, https://doi.org/10.1021/Ac990434g, 2000.

Guazzotti, S. A., Whiteaker, J. R., Suess, D., Coffee, K. R., and Prather, K. A.: Real-time measurements of the chemical composition of size-resolved particles during a Santa Ana wind episode, California USA, Atmos. Environ., 35, 3229-3240, 2001.

Healy, R. M., Sciare, J., Poulain, L., Kamili, K., Merkel, M., Müller, T., Wiedensohler, A., Eckhardt, S., Stohl, A., Sarda-Estève, R., McGillicuddy, E., O'Connor, I. P., Sodeau, J. R., and Wenger, J. C.: Sources and mixing state of size-resolved elemental carbon particles in a European megacity: Paris, Atmos. Chem. Phys., 12, 1681-1700, https://doi.org/10.5194/acp-12-1681-2012, 2012.

Healy, R. M., Evans, G. J., Murphy, M., Sierau, B., Arndt, J., McGillicuddy, E., O'Connor, I. P., Sodeau, J. R., and Wenger, J. C.: Single-particle speciation of alkylamines in ambient aerosol at five European sites, Anal. Bioanal. Chem., 407, 5899-5909, https://doi.org/10.1007/s00216-014-8092-1, 2015.

Huang, Y., Chen, H., Wang, L., Yang, X., and Chen, J.: Single particle analysis of amines in ambient aerosol in Shanghai, Environ. Chem., 9, 202-210, https://doi.org/10.1071/EN11145, 2012.

Huang, Y., Li, L., Li, J., Wang, X., Chen, H., Chen, J., Yang, X., Gross, D. S., Wang, H., Qiao, L., and Chen, C.: A case study of the highly time-resolved evolution of aerosol chemical and optical properties in urban Shanghai, China, Atmos. Chem. Phys., 13, 3931-3944, https://doi.org/10.5194/acp-133931-2013, 2013.

Jeong, C.-H., McGuire, M. L., Godri, K. J., Slowik, J. G., Rehbein, P. J. G., and Evans, G. J.: Quantification of aerosol chemical composition using continuous single particle measurements, Atmos. Chem. Phys., 11, 7027-7044, https://doi.org/10.5194/acp11-7027-2011, 2011.

Kurtén, T., Loukonen, V., Vehkamäki, H., and Kulmala, M.: Amines are likely to enhance neutral and ion-induced sulfuric acid-water nucleation in the atmosphere more effectively than ammonia, Atmos. Chem. Phys., 8, 4095-4103, https://doi.org/10.5194/acp-84095-2008, 2008.

Lee, D. and Wexler, A. S.: Atmospheric amines - Part III: Photochemistry and toxicity, Atmos. Environ., 71, 95-103, https://doi.org/10.1016/j.atmosenv.2013.01.058, 2013.

Li, L., Huang, Z. X., Dong, J. G., Li, M., Gao, W., Nian, H. Q., Fu, Z., Zhang, G. H., Bi, X. H., Cheng, P., and Zhou, Z.: Real time bipolar time-of-flight mass spectrometer for analyzing single aerosol particles, Int. J. Mass. Spectrom., 303, 118-124, https://doi.org/10.1016/j.ijms.2011.01.017, 2011.

Liu, S., Takahama, S., Russell, L. M., Gilardoni, S., and Baumgardner, D.: Oxygenated organic functional groups and their sources in single and submicron organic particles in MILAGRO 2006 campaign, Atmos. Chem. Phys., 9, 6849-6863, https://doi.org/10.5194/acp-9-6849-2009, 2009.

Liu, Y., Han, C., Liu, C., Ma, J., Ma, Q., and He, H.: Differences in the reactivity of ammonium salts with methylamine, Atmos. Chem. Phys., 12, 4855-4865, https://doi.org/10.5194/acp12-4855-2012, 2012.
Lloyd, J. A., Heaton, K. J., and Johnston, M. V.: Reactive uptake of trimethylamine into ammonium nitrate particles, J. Phys. Chem. A, 113, 4840-4843, https://doi.org/10.1021/jp900634d, 2009.

Malloy, Q. G. J., Li Qi, Warren, B., Cocker III, D. R., Erupe, M. E., and Silva, P. J.: Secondary organic aerosol formation from primary aliphatic amines with $\mathrm{NO}_{3}$ radical, Atmos. Chem. Phys. 9, 2051-2060, https://doi.org/10.5194/acp-9-2051-2009, 2009.

Moffet, R. C., de Foy, B., Molina, L. T., Molina, M. J., and Prather, K. A.: Measurement of ambient aerosols in northern Mexico City by single particle mass spectrometry, Atmos. Chem. Phys., 8, 4499-4516, https://doi.org/10.5194/acp-8-4499-2008, 2008.

Murphy, S. M., Sorooshian, A., Kroll, J. H., Ng, N. L., Chhabra, P., Tong, C., Surratt, J. D., Knipping, E., Flagan, R. C., and Seinfeld, J. H.: Secondary aerosol formation from atmospheric reactions of aliphatic amines, Atmos. Chem. Phys., 7, 2313-2337, https://doi.org/10.5194/acp-7-2313-2007, 2007.

Ngwabie, N. M., Schade, G. W., Custer, T. G., Linke, S., and Hinz, T.: Volatile organic compound emission and other trace gases from selected animal buildings, Landbauforsch. Volk, 57, 273284, 2007.

Noble, C. A. and Prather, K. A.: Real-time measurement of correlated size and composition profiles of individual atmospheric aerosol particles, Environ. Sci. Technol., 30, 2667-2680, 1996.

Phares, D. J., Rhoads, K. P., Johnston, M. V., and Wexler, A. S.: Size-resolved ultrafine particle composition analysis - 2. Houston, J. Geophys. Res.-Atmos., 108, 8420, https://doi.org/10.1029/2001jd001212, 2003.

Place, P. F., Ziemba, L. D., and Griffin, R. J.: Observations of nucleation-mode particle events and size distributions at a rural New England site, Atmos. Environ., 44, 88-94, https://doi.org/10.1016/j.atmosenv.2009.09.030, 2010.

Prather, K. A., Nordmeyer, T., and Salt, K.: Real-time characterization of individual aerosol particles using time-of-flight mass spectrometry, Anal. Chem., 66, 1403-1407, 1994.

Pratt, K. A. and Prather, K. A.: Mass spectrometry of atmospheric aerosols - Recent developments and applications. Part II: On-line mass spectrometry techniques, Mass. Spectrom. Rev., 31, 17-48, 2012.

Pratt, K. A., Hatch, L. E., and Prather, K. A.: Seasonal Volatility Dependence of Ambient Particle Phase Amines, Environ. Sci. Technol., 43, 5276-5281, https://doi.org/10.1021/es803189n, 2009.

Qin, X. Y., Pratt, K. A., Shields, L. G., Toner, S. M., and Prather, K. A.: Seasonal comparisons of single-particle chemical mixing state in Riverside, CA, Atmos. Environ., 59, 587-596, https://doi.org/10.1016/j.atmosenv.2012.05.032, 2012.

Qiu, C., Wang, L., Lal, V., Khalizov, A. F., and Zhang, R.: Heterogeneous reactions of alkylamines with ammonium sulfate and ammonium bisulfate, Environ. Sci. Technol., 45, 4748-4755, 2011.

Rappert, S. and Muller, R.: Odor compounds in waste gas emissions from agricultural operations and food industries, Waste Manage., 25, 887-907, https://doi.org/10.1016/j.wasman.2005.07.008, 2005.

Rehbein, P. J. G., Jeong, C. H., McGuire, M. L., Yao, X. H., Corbin, J. C., and Evans, G. J.: Cloud and Fog Processing Enhanced Gasto-Particle Partitioning of Trimethylamine, Environ. Sci. Technol., 45, 4346-4352, https://doi.org/10.1021/es1042113, 2011.

Rogge, W. F., Hildemann, L. M., Mazurek, M. A., and Cass, G. R.: Sources of Fine Organic Aerosol .6. Cigarette-Smoke in 
the Urban Atmosphere, Environ. Sci. Technol., 28, 1375-1388, https://doi.org/10.1021/Es00056a030, 1994.

Russell, L. M., Takahama, S., Liu, S., Hawkins, L. N., Covert, D. S., Quinn, P. K., and Bates, T. S.: Oxygenated fraction and mass of organic aerosol from direct emission and atmospheric processing measured on the R/V Ronald Brown during TEXAQS/GoMACCS 2006, J. Geophys. Res.-Atmos., 114, D00F05, https://doi.org/10.1029/2008jd011275, 2009.

Sauerwein, M. and Chan, C. K.: Heterogeneous uptake of ammonia and dimethylamine into sulfuric and oxalic acid particles, Atmos. Chem. Phys., 17, 6323-6339, https://doi.org/10.5194/acp17-6323-2017, 2017.

Sauerwein, M., Clegg, S. L., and Chan, C. K.: Water Activities and Osmotic Coefficients of Aqueous Solutions of Five Alkylaminium Sulfates and Their Mixtures with $\mathrm{H}_{2} \mathrm{SO}_{4}$ at $25^{\circ} \mathrm{C}$, Aerosol Sci. Technol., 49, 566-579, https://doi.org/10.1080/02786826.2015.1043045, 2015.

Silva, P. J., Erupe, M. E., Price, D., Elias, J., Malloy, Q. G. J., Li, Q., Warren, B., and Cocker, D. R.: Trimethylamine as precursor to secondary organic aerosol formation via nitrate radical reaction in the atmosphere, Environ. Sci. Technol., 42, 4689-4696, https://doi.org/10.1021/Es703016v, 2008.

Sorooshian, A., Ng, N. L., Chan, A. W. H., Feingold, G., Flagan, R. C., and Seinfeld, J. H.: Particulate organic acids and overall water-soluble aerosol composition measurements from the 2006 Gulf of Mexico Atmospheric Composition and Climate Study (GoMACCS), J. Geophys. Res.-Atmos., 112, D13201, https://doi.org/10.1029/2007jd008537, 2007.

Sorooshian, A., Murphy, S. M., Hersey, S., Gates, H., Padro, L. T., Nenes, A., Brechtel, F. J., Jonsson, H., Flagan, R. C., and Seinfeld, J. H.: Comprehensive airborne characterization of aerosol from a major bovine source, Atmos. Chem. Phys., 8, 5489-5520, https://doi.org/10.5194/acp-8-5489-2008, 2008.

Wang, G., Zhang, R., Gomez, M. E., Yang, L., Levy Zamora, M., Hu, M., Lin, Y., Peng, J., Guo, S., Meng, J., Li, J., Cheng, C., Hu, T., Ren, Y., Wang, Y., Gao, J., Cao, J., An, Z., Zhou, W., Li, G., Wang, J., Tian, P., Marrero-Ortiz, W., Secrest, J., Du, Z., Zheng, J., Shang, D., Zeng, L., Shao, M., Wang, W., Huang, Y., Wang, Y., Zhu, Y., Li, Y., Hu, J., Pan, B., Cai, L., Cheng, Y., Ji, Y., Zhang, F., Rosenfeld, D., Liss, P. S., Duce, R. A., Kolb, C. E., and Molina, M. J.: Persistent sulfate formation from London Fog to Chinese haze, P. Natl. Acad. Sci. USA, 113, 13630-13635, https://doi.org/10.1073/pnas.1616540113, 2016.
Wang, L., Khalizov, A. F., Zheng, J., Xu, W., Ma, Y., Lal, V., and Zhang, R. Y.: Atmospheric nanoparticles formed from heterogeneous reactions of organics, Nat. Geosci., 3, 238-242, https://doi.org/10.1038/NGEO778, 2010.

Wang, Y. Q.: MeteoInfo: GIS software for meteorological data visualization and analysis, Meteorol. Appl., 21, 360-368, https://doi.org/10.1002/met.1345, 2014.

Williams, B. J., Goldstein, A. H., Kreisberg, N. M., Hering, S. V., Worsnop, D. R., Ulbrich, I. M., Docherty, K. S., and Jimenez, J. L.: Major components of atmospheric organic aerosol in southern California as determined by hourly measurements of source marker compounds, Atmos. Chem. Phys., 10, 11577-11603, https://doi.org/10.5194/acp-10-11577-2010, 2010.

$\mathrm{Wu}, \mathrm{C}$. and $\mathrm{Yu}, \mathrm{J}$. Z.: Evaluation of linear regression techniques for atmospheric applications: the importance of appropriate weighting, Atmos. Meas. Tech., 11, 1233-1250, https://doi.org/10.5194/amt-11-1233-2018, 2018.

Wu, C., Wu, D., and Yu, J. Z.: Quantifying black carbon light absorption enhancement with a novel statistical approach, Atmos. Chem. Phys., 18, 289-309, https://doi.org/10.5194/acp-18-2892018, 2018.

Zauscher, M. D., Wang, Y., Moore, M. J. K., Gaston, C. J., and Prather, K. A.: Air Quality Impact and Physicochemical Aging of Biomass Burning Aerosols during the 2007 San Diego Wildfires, Environ. Sci. Technol., 47, 7633-7643, https://doi.org/10.1021/es4004137, 2013.

Zhang, G., Bi, X., Chan, L. Y., Li, L., Wang, X., Feng, J., Sheng, G., Fu, J., Li, M., and Zhou, Z.: Enhanced trimethylaminecontaining particles during fog events detected by single particle aerosol mass spectrometry in urban Guangzhou, China, Atmos. Environ., 55, 121-126, 2012. 